Historic, Archive Document

Do not assume content reflects current scientific knowledge, policies, or practices. 
WHOLESAlE PRREE LIST OF TENWESSEE GROWN TREES $\infty \propto \infty \times \infty$

\section{Southern Nursery Company}

WINCHESTER, TENN.

ascosecosen

Use the Nurseryman's Telegraph Code in Telegraphing

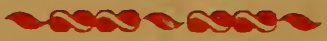

H. N. CAMP, President

E. W. CHATTIK, Secy. and Treas.

- a)oasea

REFERENCES-DUN'S COMMERCIAL AGENCY, BRADSTREET'S COMMERCIAL AGENCY, ANY BANK OR BUSINESS HOUSE IN WINCHESTER 


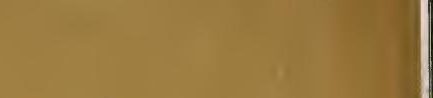




\section{= Announcement $=$}

To those who are unacquainte: with us we desire to say that we have been in the Nursery Business for f:rty years. We have 80 acres in Nursery stcck. We solicit correspondence and inspection of our stock.

\section{LOCATION}

We are 40 miles directly north of Huntsville, Ala., on the main line of the Nashville, Chattanooga \& St. Louis Railway sistein and no point has better shipping facilities. We can get a direct line to any part of the country at the low sst rate and shortest time.

\section{RATES}

Fifty trees of not less than 10 of a variety will be furnished at 100 rates, 250 trees of not less than 10 of a variety at thousand rates. Long lists of varieties of a few trees of a kind subject to higher prices.

\section{PACKING AND COST OF PACKING}

Our packing season usually opens October 1st and continues to April 1st. We handle stock most of t? $-\mathrm{e}$ winter in our cool storage buildings.

The cost of boxes 9 to 10 feet long, $30 \times 30$ inches, $\$ 2.50$; $24 \times 24$ inches, $\$ 2.25 ; 20 \times 20$ inches, $\$ 2.00 ; 18 \times 18$ inches, $\$ 1.60$. Twelve-foot boxes, 50 cents extra.

Bales, $25 \mathrm{c}$ to $\$ 2.00$, according to size.

No charge for packing in bulk in car load lots.

\section{SHIPPING}

We prefer parties ordering to indicate how goods must be sent, whether by freight or express, alsn route. If no such directions are given we forward to the best of our judgment, but in no case do we assume responsibility. When losses occur claims should be made to the transportation company immeriately.

\section{GUARANTEE OF GENCINENESS}

We exercise the greatest care to keep all of our stock pure and true to label and are ready, on proper proof, to replace any that may prove untrue, free of charge, or refund the purchase price, but it is mutually understood and agried, between purchaser and ourselves, that we are not liable for any greater sum than that paid us for said trees, etc., that may prove untrue. 


\section{STORAGE AND PACKING}

We have a cool storage warehouse with a capacity of 40 to 50 car loads with an addition to it to be used as a packing house and, being located on a switch from the Nashville, Chattanooga \& St. Louis Railroad, we can handle stock at any time in the winter season.

All of our packing is under the direct supervision of a member of our firm and it is done right and you may depend on the goods reaching you in prime condition.

\section{CAUTION}

We accept orders upon the condition that they shall be void should anything befall our stock from frost, hail, storm, fire, or other causes over which we have no control.

\section{CLAIMS}

All claims for errors must be made on receipt of goods to receive consideration. Complaints made after the goods have been in the hands of the purchaser ten days can not be entertained.

\section{CODE}

In telegraphing use Nurseryman's Telegraph Code, copies of which we will mail you on request.

\section{TERMS OF PAYMENT}

Cash or satisfactory security or reference to parties unknown to us. All orders to be sent C. O. D. must be accompanied with one-fourth the amount in cash.

\section{CHANGE OF PRICES}

The prices given in this list are subject to change without notice and to the stock being unsold at the time the order is received.

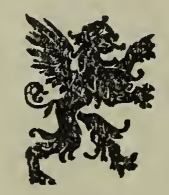




\section{APPLES-One and Two Year Grafts}

Per 100 Per 1000

5 to 7 feet, 11-16 inch and up .......... $\$ 1500$

4 to 6 feet, $5-8$ to $11-i 6$ inch .............. 1250

3 to 5 feet, $1-2$ to 5.8 inch _.............. 900

3 to 4 feet, partly branched ................ 700

4 to 5 ieet, one year grafts ................. 800

3 to 4 feet, one year grafts ............... 600

Leading Varieties-

$\begin{array}{ll}\text { Alexander } & \text { Northern Spy } \\ \text { Benoni } & \text { N. W. Greening } \\ \text { Ben Davis } & \text { Rambo } \\ \text { *Baldwin } & \text { Red Astrachan } \\ \text { Clayton } & \text { R. I. Greening } \\ \text { Domine } & \text { *Rome Beauty } \\ \text { *Dutchess } & \text { Smith's Cider } \\ \text { *Early Harvest } & \text { Stark } \\ \text { Gano } & \text { *Staymen Winesap } \\ \text { Golden Sweet } & \text { *Wealthy } \\ \text { *Grimes' Golden } & \text { Winesap } \\ \text { *Jonathan } & \text { *Winter Banana } \\ \text { King } & \text { Wagener } \\ \text { Mann } & \text { Wolf River } \\ \text { Maiden Blush } & \text { *Yellow Transparent } \\ \text { Mammoth Black Twig } & \text { Yellow Bellfower } \\ \text { Missouri Pippin } & \text { Whitney Crab } \\ \text { Varieties marked (*) } 2 c \text { extra if furnished alone. }\end{array}$

\section{APPLES, One Year Buds}

Very fine trees

Per 100 Per 1000

4 to 5 feet, whips

$\$ 8000$

3 to 4 feet, whips

6000

2 to 3 feet, whips

4000

Leading Varieties-

Baldwin

Dutchess

Grimes

Jonathan

Northern Spy

Wealthy

N. W. Greening

800
, 


\section{PEAR, Standard, Two Year Old}

Assortment of varieties

Per 100 Per 1000

5 to 7 feet, 3.4 inch and up

$\$ 1400$

4 to 6 feet, 5-8 to $3-4 \mathrm{inch}$

1100

3 to 5 feet, $1-2$ to $5-8$ inch

800

3 to 4 feet

500

\section{PLUM on Plum}

5 to 7 feet, 3-4 inch and up

Per 100

4 to 6 feet, $5-8$ to $3-4$ inch

3 to 5 feet, $1-2$ to $5-8$ inch 1000

Leading Varieties-

$\begin{array}{ll}\text { Abundance } & \text { Pond's Seedling } \\ \text { Burbank } & \text { Rlene Claude } \\ \text { Geuii } & \text { Shipper's Pride } \\ \text { German Prune } & \text { Tatge } \\ \text { Hawkeye } & \text { Wickson } \\ \text { Lombard } & \text { Wyant } \\ \text { Moore's Arctic } & \text { Wolf }\end{array}$

\section{CHERRY, Two Year, on Mahaleb}

Per 100 Per 1000

4 to 6 feet, 3-4 inch and up

$\$ 1000 \quad \$ 10000$

4 to 5 feet, $5-8$ to $3-4$ inch

7500

3 to 4 feet, $1-2$ to $5-8$ inch

800

$\begin{array}{lll}600 & 5000\end{array}$

2 to 3 feet

$300 \quad 2500$

Leading Varieties-
Baldwin
Black Tartarian
English Morello
Governor Wood
Montmorency
May Duke
Olivet
Ostheim
Windsor
IVragg

Late Duke

\section{PEACH, One Year Old}

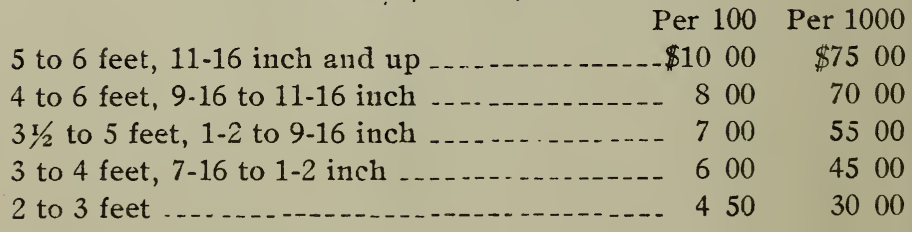

Leading Varieties-

Alexander

Beers Smock

Belle of Georgia
Heath Cling

Kalamazoo

Lemon Free

Varieties continued on page 5 


$\begin{array}{ll}\text { Bokara } & \text { New Prolific } \\ \text { Carman } & \text { Matthews Beauty } \\ \text { Champion } & \text { Mountain Rose } \\ \text { Chair's Choice } & \text { Mayfluwer } \\ \text { Capt. Ede } & \text { Old Mixon Free } \\ \text { Crawford Early } & \text { Old Mixon Cling } \\ \text { Crawford Late } & \text { Salway } \\ \text { Crosby } & \text { Smock Free } \\ \text { Elberta } & \text { Stump } \\ \text { Engel's Mammoth } & \text { Triumph } \\ \text { Fitzgerald } & \text { Wheatland } \\ \text { Foster } & \text { Wonderful } \\ \text { Globe } & \text { Yellow St. John }\end{array}$

\section{APRICOT, One Year Old on Peach}

4 to 5 feet

3 to 4 feet

Leading Varieties-

Superb

Royal

Noorpark

\section{QUINCE}

3 to 4 feet, 9-16 and up

Leading Varieties-

Champion

Meeches Prolific
Orange

Rea's Mammoth

\section{GOOSEBERRY}

Downing, 2 year No. 1._._.

1 year No. 1 _.............................. 500

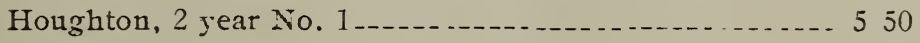

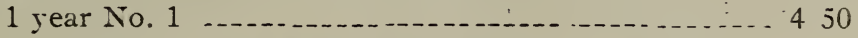

\section{CURRANTS}

2 year No. 1, assorted

Per 100 Per 1000

$\$ 400 \$ \$ 3500$

1 year No. 1, assorted

Leading Varieties-

$\begin{array}{ll}\text { London Market } & \text { Red Dutch } \\ \text { North Star } & \text { Victoria } \\ \text { Pomona } & \text { Wilder }\end{array}$

2 year No. 1

1 year No. 1

Leading Varieties-

Fay's Prolific

Lee's Prolific

White Grape

Cherry 


\section{ROOT GRAFTS}

We make a specialty of putting up root grafts each winter for the trade and prile surselves on our workmabship in this line. Will be pleased to qurte prices on application. ANY STYLE OF GRAFT MADE TO ORDER.

\section{APPLE SEEDLINGS}

3-16 inch and up, straight ........... Prices on application

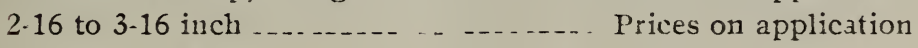

\section{FOREST TRES SEEDLINGS}

Catalpa Speciosa, 6 to 12 inches

Per 1000 12 to 18 inches........ $\$ 150$

18 to 24 inches............................. 300

24 to 36 inches .......................... 375

Black Locust, 12 to 18 inches .................... 250

18 to 24 inches. . . . . 300

24 to 36 inches ....................... 350

Russian Mulberry, 18 to 24 inches ................. 6 r. 0

Silver Maple, 18 to 24 inches..................... 600

\section{ORNAMENTAL TREES}

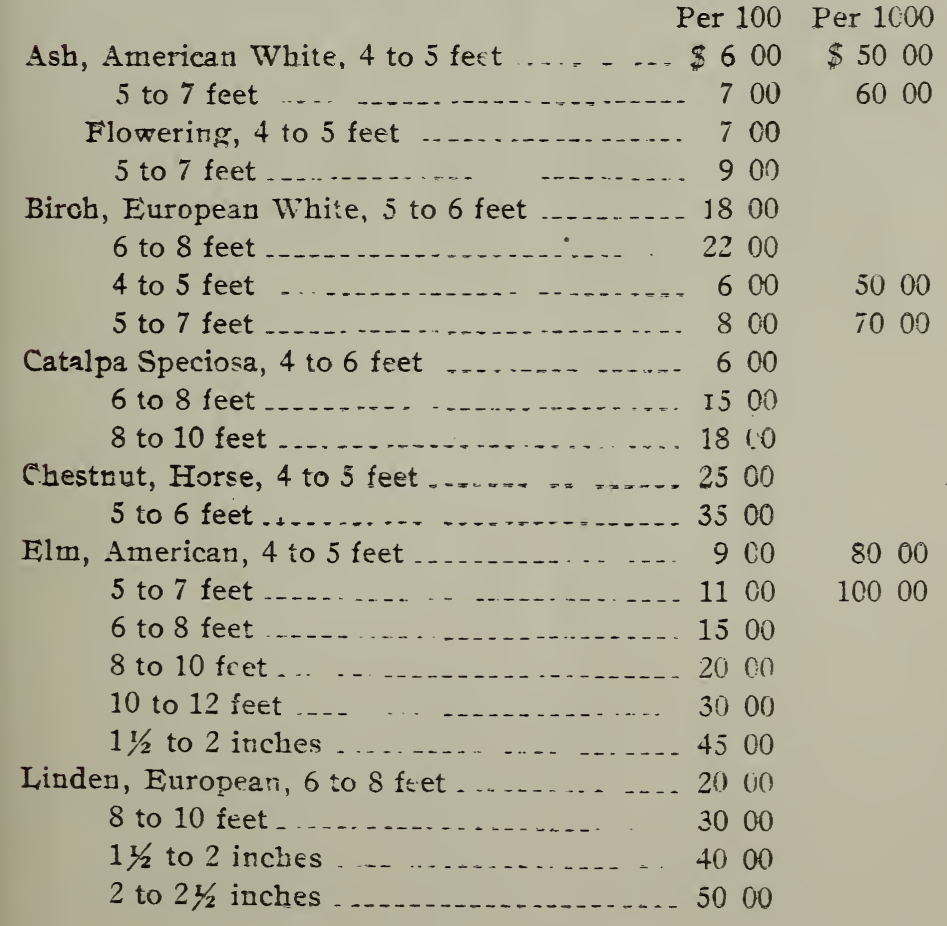




\section{ORNAIIENTAL TREES-Continued}

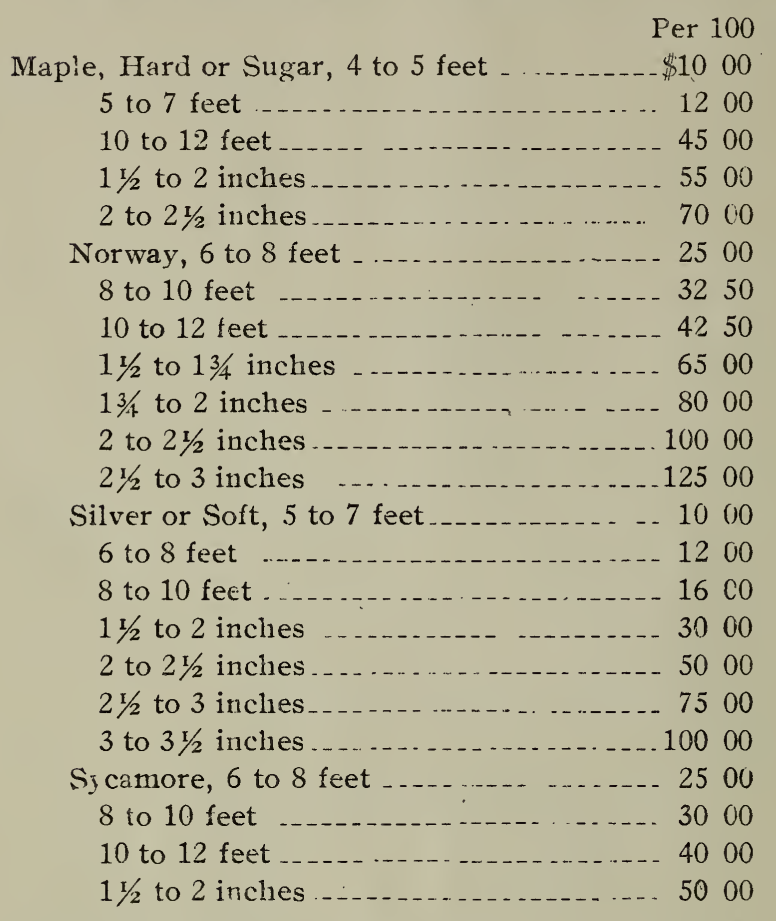

Magnolia, Accuminata, 4 to 5 feet ........ 2500

5 to 7 feet . . . . . . . . 3000

Mountai: Ash, European, 5 to 6 feet ....... 1000

6 to 8 feet ................... 1500

8 to 10 feet ........................... 2000

Oak, Pin, 6 to 8 feet ................... 3000

8 to 10 feet .......................... 4000

$11 / 2$ to 2 inches. . . . . . . 5000

2 to 3 inches........................... 7500

Plane, Orieutal Sycamore, 6 to 8 feet ... .... 2000

8 to 10 feet ..................... 2500

$11 / 2$ to 2 inches.......................... 4500

2 to $21 / 2$ inches ..................... 6000

$21 / 2$ to 3 inches

Horse Chestnut, 4 to 5 feet............. 2000

5 to 6 feet . . . . . . . . . . 2500

6 to 8 feet ..................... 3500

Poplar, Carolina, 6 to 8 feet ............. 600

8 to 10 feet ......................... 800

10 to 12 feet ..................... 1200

$11 / 2$ to 2 inches ........................ 2000

2 to $21 / 2$ inclaes ....................... 3000 


\title{
ORNAMENTAL TREES-Continued
}

\author{
Per 100 Per 1000 \\ Volga, 6 to 8 feet \\ $\$ 800$ \\ 8 to $\mathrm{i} 0$ feet ....................... 1000 \\ 10 to 12 feet ........................ 1500 \\ Tulip Tree, 6 to 8 feet -...-.............. 1000

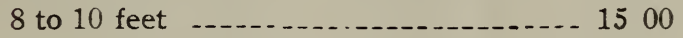

\section{WEEPING TREES}

Birch, Cut Leaf, 4 to 5 feet............ 2500

5 to 6 feet _.......... 3000

6 to 8 feet . . .

Young's, 3 to 4 feet..................... 3500

4 to 5 feet .................... 4000

Willow, Kiluarnock, 1 year heads ......... 3500

Mulberry, Teas, 1 year hesds ............. 4500

2 year heads ....................... 6000

Maple, Wier's Cut Leaf, 4 to 5 feet .......... 1500

5 to 8 feet .......................... 2000

\section{DECIDUOUS SHRUBS}

Altheas, Named colors, 2 to 3 feet ......... \$800

3 to 4 feet ......................... 1000

Barberry, Purple Leaf, 1 to $1 \frac{1}{2}$ feet ........ 400

$11 / 2$ to 2 feet ...................... 500

2 to 3 feet ........................... 600

3 to 4 feet ........................... 800

Thunbergii, 1 to $1 \frac{1}{2}$ feet ............ 600

$11 / 2$ to 2 feet

2 to 3 feet . . . . . . . . 1000

Calycanthus, 1 r $/ 2$ to 2 feet .............. 600

2 to 3 feet ...

Dogwood, Siberian, 2 to 3 feet............. 600

3 to 4 feet ......................... 800

Stolonifera, $11 / 2$ to 2 feet .............. 500

2 to 3 feet ....................... 700

Cydonia, Japonica, $1 \frac{1}{2}$ to 2 feet .......... 400

2 to 3 feet

Deutzia, Crenata fl. pl. Candirissima

Grassilis, 2 to 3 feet ............... 700

3 to 4 feet ......................... 900

Pride of Rochester, Lemonei, 2 to 3 feet - 800

3 to 4 feet ......................... 1000

Eleagnus Longipes, $1 \frac{1 / 2}{2}$ to 2 feet .......... 600

2 to 3 feet .......................... 800

Enonomous, Americanus, 2 to 3 feet........ 600

3 to 4 feet .......... 


\section{DECIDUOUS SHRUBS-Continued}

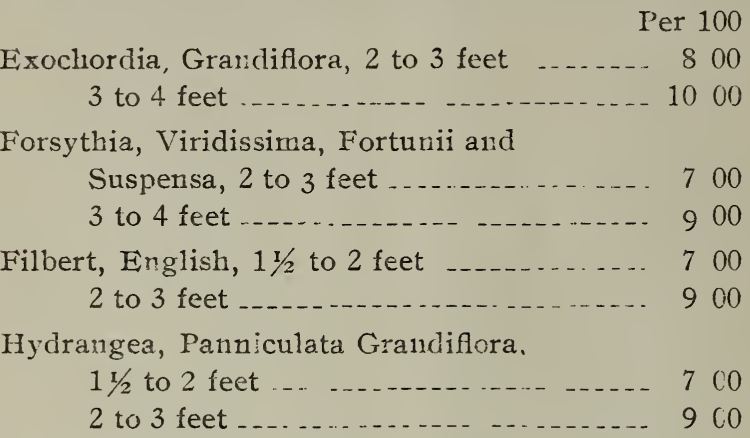

Honeysuckle, Red and White Tartarian

Morrowii, Fragrantissima, 2 to 3 feet -- 600 3 to 4 feet ..................... 8 c0

Lilac, Purple and White, $1 \frac{1}{2}$ to 2 feet ..... 610 2 to 3 feet ................ 700

Persian Purple, Chas. X. Villosa, $1 \frac{1}{2}$ to 2 fect .................... 800

2 to 3 feet ...

Philadelphus, Syringia, Grandiflora and

Erecta, 2 to 3 feet ............. 800 3 to 4 feet .................. 1000

Rhus, Virginiana, 3 to 4 feet ............... 800 4 to 5 feet ...... . . . . . . . . . . . . . 1000 5 to 6 feet ......................... 1200

Typhina (fern leaf), 3 to 4 feet ... ..... 800 4 to 5 feet ...................... 1000 5 to 6 feet ...................... 1200

Sambucus, Aurea (gold 1f. elder), 2 to 3 feet. 500 3 to 4 feet ..................... 700

4 to 5 feet .......................... 1000

Nicra, 2 to 3 feet ................... 600

3 to 4 feet ......................... 8 c0

Spirea, Anthony Waterer, $1 \frac{1}{2}$ to 2 feet ...... 800

Opuiifolia, 3 to 4 feet . ................ 800 4 to 5 feet ..................... 1000

Opulifolia Aurea, 3 to 4 feet. ........... 1000 4 to 5 feet .... ................. 1200

Van Houttii, 3 to 4 feet.............. 600 4 to 5 feet .......................... 800

Snowbery, Red aud White, 2 to 3 feet ... 700 3 to 4 feet ... . . . . . . . . . 800

Viburnum, Common Snowball, $1 \frac{1}{2}$ to 2 feet.- 600 2 to 3 feet ................... 800 


\section{DECIDUOUS SHRUBS-Continued}

Japan Snowball, $11 / 2$ to 2 feet........... Per 100

2 to 3 feet ... _................. 900

High Bush Cranberry, $11 / 2$ to 2 feet ...... 600

2 to 3 feet.............. 800

Weigelia, 2 to 3 feet _._._.......... 700

3 to 4 feet _........... 900

Eva Ratke, Abel Carier, Yellow and

Variegated, 2 to 3 feet ............. 800

3 to 4 feet ....................... 1000

\section{CLIMBING VINES}

Ampelopsis, Quinquifolia, 2 year strong _....\$5 00 Engelmanii, 2 year strong ............. 700

Veitchii, 2 year _...................... 1000

Akebia, Quinita, 2 year strong ............ 600

Bignonia, Radicans and Coccenia, 2 year -..- 700

Clematis, Panniculata_._._._._._. 1000

Large flowered sorts _._._._._.

Aristolocha, Dutchman's Pipe _............ 2000

Honeysuckle, Assorted............... 800

Matrimony Vine........................ 600

Wistaria, Magnifica and Multijuga_ _..._._. 1000

\section{EVERGREENS}

Arbor Vitae, American, 1 to $1 \frac{1}{2}$ feet_...... $\$ 500$

$11 / 2$ to 2 feet

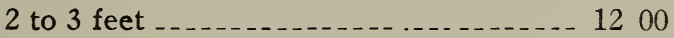

American Arbor Vitae, 3 to 4 feet ......... _ 1500

Pine, White, 1 to $11 / 2$ feet .......... 600

$11 / 2$ to 2 feet

2 to 3 feet ........... 1200

3 to 4 feet _............. 1800

Spruce, Norway, $11 / 2$ to 2 feet ............ 800

2 to 3 feet ........ 1000

3 to 4 feet ................ 1500

Colorado Blue, 1 to $1 \mathrm{r} / 2$ feet . . . . . . . 3000

$11 / 2$ to 2 feet

Koster's Grafted, $11 / 2$ to 2 feet -....... 7500

2 to $21 / 2$ feet .................... 10000

Magnolia Grandiora, 2 to 3 feet ............ 2500 


\section{ROSES, Field Grown on Own Roots}

No. 1 at $12 \frac{1}{2} \mathrm{c}$

No. 2 at $8 \mathrm{c}$

Leading Varicties-

Paul Neyron

Baby Rambler

Gen. Jack

W. R. Smith

Ulrich Bruner

Marechal Neil

Pink Cochet

White Cochet

Mamon Cochet

Puritan

\section{PEACH SEED, Tennessee Naturals}

Per bushel

\section{APPLE SEEDLINGS}

No. 1, per 1000, at ........... $\$ 450$

No. 2, per 1000, at

\section{JAPAN PEAR SEEDLINGS}

No. 3 , per 1000 , at

We have fine blocks of both Alple and Peach Trecs. Our soil can not be excelled for producing good taps and roots of Apple and Peach Trees.

\section{Tennessee State Board of Entomology KNOEVILLE, TENN.}

Catstificate of Nursery Inspection, Number 91.

Season 1912.13

T: IS IS TO CERTIFY, That in accordance with an Act of the I,egislature, a puroved April 17, 1905, the nursery g! Ounds of SOUTHERN NURSERYCo., at II menester, County of Franklin, state of Tennessee, were inspected by $\mathbf{C}$.' $\mathbf{R}$. Spat.gler and J. E. Blake on Aug. 12, 13, 14, 15, 16, 17, 19т2. The growing nursety stock was apparently free from San Jose Scaie and other dangerously injurious insect pests and plant diseases.

Sa'd nursery is equipped for fumigating all nursery stock.

This certificate has reference to unsects and diseases, and is not otherwise $t=$ be cousidered as an endorsement of the parties to whom issued; it does 1 it aprly to stoch net grown in the aforc-said nurseries unless stock is coveret by proner certificate in favor of the Nursery where grown. It is not transtelahle and may be revoked for cause.

This certificate becomes invalid after August 1,1913 and cannot be legally used oftei that date. 

